\title{
Effects of Different Selection Methods Using Body Weight on Egg Yield Parameters in Japanese Quail
}

\section{-Author(s)}

Baylan M

Cukurova Universitesi - Animal Science Cukurova University Agricultural Faculty Department of Animal Science, Adana/ TURKEY Adana 01330 Turkey

\section{Mail Address}

Corresponding author e-mail address Mikail Baylan

Cukurova Universitesi - Animal Science

Cukurova University Agricultural Faculty Department of Animal Science, Adana/ TURKEY Adana 01330 Turkey

Tel: $\quad$ +90 5064079879

Email: mikailbaylan@gmail.com

\section{neywords}

Body weight, egg production, egg weight, Japanese quail selection.

\section{ABSTRACT}

This experiment was conducted to investigate the effects of different selection methods of parent lines on the body weight of Japanese quails. For this purpose, line $M_{55}$ was subjected to individual selection for body weight at 5 weeks of age, while a reciprocal recurrent selection method was applied to lines $R_{33}$ and $S_{55}$. Selection lasted two generations. Body weight changes, age and weight at sexual maturity, egg weight, and egg production were investigated in the parent generations as well as in the selection lines. Body weight at 5 weeks of age of the parents of the $M_{55}, R_{33}$ and $S_{55}$ lines were 299.0, 285.3, and $280.4 \mathrm{~g}$ in the first generation, and $314.8,316.6$, and $306.8 \pm 3.11 \mathrm{~g}$ in the second generation, respectively. The first generation of the $M_{55}, R_{33}$, and $S_{55}$ lines presented egg production rates of $73.4,77.6$, and $75.8 \%$, respectively, and egg weights of $12.7,11.9$, and $12.1 \mathrm{~g}$, respectively. The second generation of the $M_{55}, R_{33}$ and $S_{55}$ lines presented egg production rates of $74.6,77.8$, and $78.3 \%$, and egg weights of $12.72,12.59$, and 12.56 $\mathrm{g}$, respectively. Both egg production and egg weights were significantly different between the first and the second generations ( $p>0.05)$. As a result, despite significant increase in body weight of the selection lines, no significant differences in egg production or egg weight were determined among generations. However, reciprocal selection lines of both generations presented higher egg yield than the individual selected line.

\section{INTRODUCTION}

Japanese quails are commercially produced mainly for meat in Europe and for eggs in Japan, and are often bred as dual-purpose poultry in other Asian countries (Minvielle, 1998; Kayang et al., 2004; Maiorano et al., 2012). Recently, quail meat has begun to attract the consumers, but most producers find it difficult to obtain superior quality parents. For this purpose, especially for the production of fast-growing birds, researchers have been working on Japanese quail parent strains with high growth potential.

Selection has an important role for the genetic improvement of livestock. Individual selection, in particular, is essential in experiments for selection for body weight (BW) in poultry, and the high heritability of body weight provides major benefits (Hussein et al., 2014). Many researchers have reported that the heritability of BW in Japanese quails is moderate to high (Darden \& Marks, 1988; Marks, 1989; Kocak et al., 1995; Marks, 1996; Baylan et al., 2009a; Sarı et al., 2011; Narinc \& Aksoy, 2014, Kaye et al., 2016). Selection experiments applying different selection methods in different environments have been performed, but most involved individual selection and used BW at 3, 4, and 5 weeks of age as the criterion. 
Experiments using selection methods have also been carried out to evaluate heterosis. Reciprocal recurrent selection, which involves two types of selection in favor of additive and nonadditive genetic variation, is an important breeding method to obtain heterosis and stable genetic lines. First developed by Comstock et al. (1949), this method enables the selection and combination of preferred capable lines. That is to say, reciprocal recurrent selection designed to increase the genetic distance between lines should eventually achieve maximum heterosis. This is even more so in the negative correlation between body weight and egg production. This situation should be considered in the development of quail parent lines (Kocak et al., 1995; Minvielle et al., 1999; Yahaya et al., 2009). It is reported that the long-term selection for body weight in quails has resulted in a decrease in egg production and an increase in egg weight. Usually, a significant increase in egg production causes a decrease in egg weight. This is applicable for quails as well, and it is an important measure for selection for body weight (Marks, 1996, Alkan et al., 2010; Silva et al. 2013).

This study investigated the change in egg production and egg weight in genotypes bred for body weight. These two characteristics that guide the development of the maternal and paternal lines of the quail flock being worked on would be effective in the consideration as selection measures.

\section{MATERIALS AND METHODS}

The quail lines used were $M_{55}, R_{33}$ and $S_{55}$. These lines were developed previously by selection for BW in the Department of Animal Science Quail Research Unit, Agricultural Faculty at Cukurova University, Adana, Turkey. Details regarding the establishment of these lines can be found in Baylan (2003). Briefly, $M_{55}$ was obtained after nine generations of individual selection for body weight at 5 weeks of age ( 5 -wk BW). Lines $R_{33}$ and $S_{55}$ were obtained following three generations of individual selection for body weight at 3 and 5 weeks of age, respectively, followed by three generations of reciprocal recurrent selection.

In this study, line $M_{55}$ was subjected to individual selection for 5-wk BW, while reciprocal recurrent selection was applied to lines $R_{33}$ and $S_{55}$. Selection lasted for two generations.

In the $M_{55}$ line individual selection was applied for 70 parents from the quail population based on the sex ratio $\left(3 \circ: 1{ }^{\Uparrow}\right)$ per generation. Eighty males and female pullets were obtained from each generation from lines $\mathrm{R}_{33}$ and $\mathrm{S}_{55}$ and these parents were transferred to individual cages in order to perform reciprocal crosses (80 pair-matings of $R_{3} S_{5}$, and pair-matings of $S_{5} R_{3}$ ) at the end of 5 weeks of age. One male and one female were kept together in individual cages $(15 \times 25 \times 20 \mathrm{~cm})$. At week 8 of egg laying, hatching was initiated and the obtained offspring were wing-tagged and raised for five weeks. Depending on the performance of hybrid offspring in week 5 , the best male and female individuals (1:3 ratio; 9:27) were selected to determine the $R_{33}$ and $S_{55}$ parents.

After the parents were determined in all lines, at the inbreeding stage, the productivity levels of the mothers (age and weight at sexual maturity, egg production, egg weight) were compared.

During the study, the parents were fed a caged chicken egg laying feed with 15\% crude protein and $2650 \mathrm{kcal} \mathrm{ME} / \mathrm{kg}$. Feed and water were supplied ad libitum, and a lighting schedule of 16 hours light and 8 hours of darkness was applied.

In the study of all parent groups, beginning on the date of initial laying, the eggs laid were collected daily. Egg weight was determined weekly on the same day of the week for 18 weeks for each generation. All weights were measured to $0.1-\mathrm{g}$ precision.

Data were analyzed by one-way analysis of variance procedure of the SPSS software. Significant differences among means were ranked by Duncan's Multiple Range Test (Windows version of SPSS, release 10.01).

\section{RESULTS AND DISCUSSION}

Five-week body weights of the parents of $M_{55}, R_{33}$ and $S_{55}$ lines were determined as 299.0, 285.3, and $280.4 \mathrm{~g}$ for the first generation; 314.8, 316.6, and $306.8 \pm 3.11 \mathrm{~g}$ for the second generation (Tables 1 and 2). The body weight differences among lines in the first and the second generation were statistically significant $(p<0.05)$. Higher body weight was obtained in the second generation compared with the first generation. These results are consistent with Baylan et al. (2009a), who obtained for the $M_{55}, R_{33}$ and $S_{55}$ lines 5-wk BW of 282.9, 284.8, and $279.5 \mathrm{~g}$ for the first generation, and 284.6, 285.5, and $284.3 \mathrm{~g}$ for the second generation, respectively. Those researchers reported that the 5-wk BW differences among lines were statistically significant in the first generation $(p<0.05)$, and reported that, at the end of the second generation, 5-wk BW increased in 11.1, 26.6, and 25.3 $\mathrm{g}$ compared with the initial generations of the $M_{55}, R_{33}$ and $S_{55}$ lines, respectively. Baylan et al. (2009b) also 
reported that, among individual lines, the percentage deviation of 5-wk BW was 2.19 and $6.29 \%$ in the first and second generation, respectively.

The egg production and 5-wk BW values of female individuals of the first and second generations of the selection lines are given in Tables 1 and 2 . In both generations, selection lines were housed in the laying cages at 5 weeks of age. Egg production, starting in week 6, was calculated as quail-day average by dividing the number of eggs by the number of surviving hens, and expressed in as a weekly percentage (\%) and cumulative egg production during 18 weeks of evaluation for both generations.

Age at sexual maturity was reached at $38,45.1$, and 46.8 days in the first generation and $38,46.3$ and 46.6 days in the second generation of the $\mathrm{M}_{55}, \mathrm{R}_{33}$, and $\mathrm{S}_{55}$ lines, respectively. Body weights at sexual maturity were
$317.9,333.5$, and $337.9 \mathrm{~g}$ in the first generation and $331.8,358.2$, and $352.3 \mathrm{~g}$ in the second generation of the $M_{55}, R_{33}$, and $S_{55}$ lines, respectively. Daikwo et al. (2014) reported that the mean body weight at first egg was $145.68 \mathrm{~g}$ and mean age at first egg was 47.01 days. The body weight at first egg obtained in the present study was higher than that reported by Daikwo et al. (2014), but mean age at first egg was similar.

Average egg production at 20 weeks in the first generation of the $M_{55}, R_{33}$ and $S_{55}$ lines was $73.4,77.6$, and $75.8 \%$, and $74.6,77.8$, and $78.3 \%$ in the second generation, respectively.

Egg production per quail of the first generation (18 weeks) of the $\mathrm{M}_{55}, \mathrm{R}_{33}$ and $\mathrm{S}_{55}$ lines was $93.2,96.6$, and 94.7 eggs, respectively, and in the second generation (18 weeks) 94.3, 96.5 and 97.3, respectively.

Table 1 - Body weight at 5 weeks of age and egg production values of the first generation of Japanese quails according to selection line $\left(^{*}\right)$

\begin{tabular}{lccc}
\hline \multirow{2}{*}{ Parameters } & Individual selection line & \multicolumn{2}{c}{ Reciprocal selection lines } \\
\cline { 2 - 4 } & $\mathrm{M}_{55}$ & $\mathrm{R}_{33}$ & $\mathrm{~S}_{55}$ \\
\hline 5-wk body weight (g) & $299.0 \pm 3.03^{\mathrm{a}}$ & $285.3 \pm 3.01^{\mathrm{b}}$ & $280.4 \pm 2.80^{\mathrm{b}}$ \\
Age at sexual maturity (d) & 38.0 & 45.1 & 46.8 \\
Body weight at sexual maturity (g) & $317.9 \pm 2.58$ & $333.5 \pm 3.16$ & $337.9 \pm 3.63$ \\
Egg production in 20 weeks (n) & 93.2 & 96.6 & 94.7 \\
Egg production (\%) & $73.4 \pm 3.32^{\mathrm{b}}$ & $77.6 \pm 4.34^{\mathrm{a}}$ & $75.8 \pm 4.65^{\mathrm{a}}$ \\
Egg weight week 1 $(\mathrm{g})$ & $10.2 \pm 0.71$ & $9.2 \pm 0.50$ & $9.6 \pm 0.80$ \\
Egg weight week 15 $(\mathrm{g})$ & $13.3 \pm 0.16^{\mathrm{a}}$ & $12.54 \pm 0.13^{\mathrm{b}}$ & $12.5 \pm 0.14^{\mathrm{b}}$ \\
Average egg weight $(\mathrm{g})$ & $12.7 \pm 0.06^{\mathrm{a}}$ & $11.9 \pm 0.04^{\mathrm{c}}$ & $12.1 \pm 0.04^{\mathrm{b}}$ \\
\hline
\end{tabular}

$\left({ }^{*}\right)$ Significant differences $(p<0.05)$ among the overall means of the selection lines are indicated by different letters $(a, b, c)$.

Table 2 - Body weight at 5 weeks of age and egg production values of the second generation of Japanese quails according to selection line $\left(^{*}\right)$

\begin{tabular}{lccc}
\hline \multirow{2}{*}{ Parameters } & Individual selection line & \multicolumn{2}{c}{ Reciprocal selection lines } \\
\cline { 2 - 4 } & $\mathrm{M}_{55}$ & $\mathrm{R}_{33}$ & $\mathrm{~S}_{55}$ \\
\hline 5-wk body weight (g) & $314.8 \pm 2.90^{\mathrm{a}}$ & $316.6 \pm 4.14^{\mathrm{a}}$ & $306.8 \pm 3.11^{\mathrm{b}}$ \\
Age at sexual maturity (d) & 38 & 46.3 & 46.6 \\
Body weight at sexual maturity $(\mathrm{g})$ & $331.8 \pm 2.07$ & $358.2 \pm 2.92$ & $352.7 \pm 3.16$ \\
Egg production in 20 weeks $(\mathrm{n})$ & 94.3 & 96.5 & 97.3 \\
Egg production (\%) & $74.6 \pm 5.58^{\mathrm{b}}$ & $9.3 \pm 4.47^{\mathrm{a}}$ & $78.3 \pm 4.43^{\mathrm{a}}$ \\
Egg weight week 1 (g) & $9.7 \pm 0.57$ & $13.4 \pm 0.13^{\mathrm{a}}$ & $10.8 \pm 0.57$ \\
Egg weight week 15 $(\mathrm{g})$ & $12.8 \pm 0.19^{\mathrm{b}}$ & $12.5 \pm 0.05$ & $13.5 \pm 0.15^{\mathrm{ab}}$ \\
Average egg weight $(\mathrm{g})$ & $12.7 \pm 0.07$ & $12.5 \pm 0.05$ \\
\hline
\end{tabular}

$\left({ }^{*}\right)$ Significant differences $(p<0.05)$ among the overall means of the selection lines are indicated by different letters $(a, b)$.

As demonstrated both in Tables 1 and 2 and these values and in Figures 1 and 2, the egg production of the selection lines did not change between generations; however, in both generations, the cross selection lines $\left(R_{33} S_{55}\right)$ presented higher egg production values compared to the individual selection line $\left(\mathrm{M}_{55}\right)$.
In a study on the long-term selection for 4-week body weight in Japanese quails, Marks (1979) reported average egg production in all generations of $75.8 \%$ in the selected group and $81.1 \%$ in the control group, and emphasized that selection based on body weight causes a reduction in egg production. Anthony et al. 
(1996) also reported that correlated responses over 30 generations of divergent selection for 4-wk BW in Japanese quails indicate that selection had negative effects on fitness traits, including egg number. Durmus et al. (2017) observed the that selection for high body weight in Japanese quails led to a reduction in egg production by $13.5 \%$.

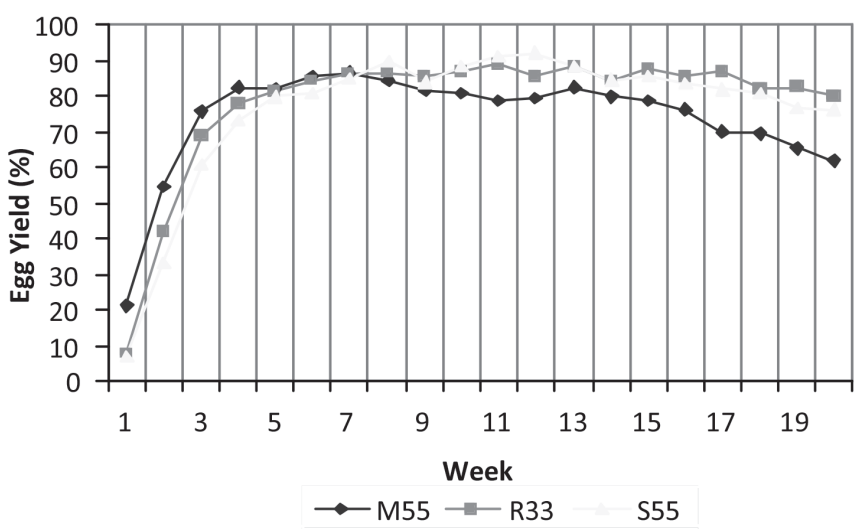

Figure 1 - Weekly egg production of the first generation of the selection lines

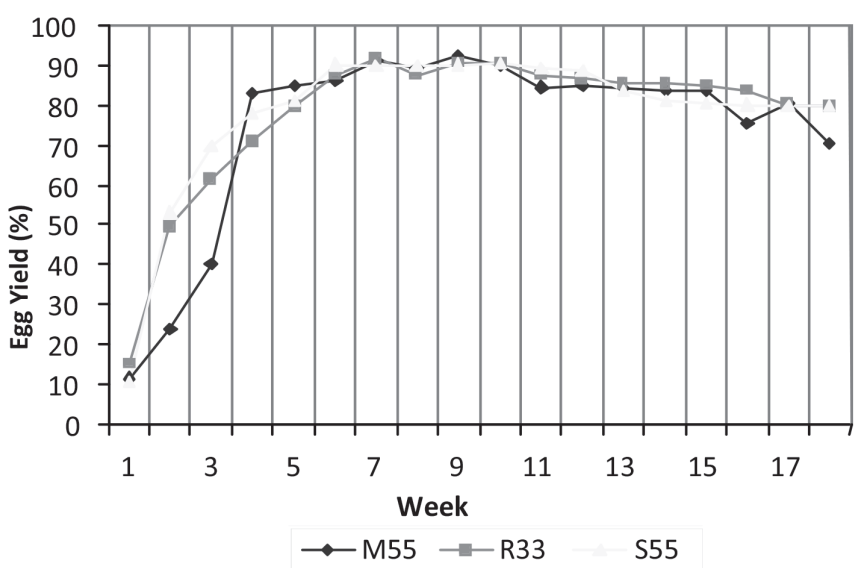

Figure $\mathbf{2}$-Weekly egg production of the second generation of the selection line

Testik et al. (1993) observed that in Japanese quails with different origins, lower egg production was obtained in the selected for body weight. Those researchers reported the 300-d egg production of 165.8 and 160.7 eggs in the Aegean-sourced control and selected groups, respectively, and 164.3 and 159.3 eggs in the Ankara-sourced control and selected groups, respectively.

On the other hand, Okan \& Uluocak (1992) reported that the 15-wk quail-day egg production varied between 51.2-77.9\%, and Nacar and Uluocak (1995) also observed egg production variability in females of different age groups, with the highest production peak over a 21 -week period of $77.9 \%$. All these values are much lower than those obtained with all the lines evaluated in the present study. Nacar et al. (1997), selecting Japanese quails for heavy and light 5-wk BW, recorded 17-wk quail-coop egg production of 95.93 eggs in the heavy group, with a percentage egg production of $80.6 \%$, and peak egg production in week 13 of $89.7 \%$. On the other hand, Inal et al. (1996) reported the egg production in the selected group between days $80-95$ as $67.33-84.58 \%$, which is close to the values recorded in the present study during the same time period. Baylan (2003) obtained in the same lines $\left(M_{55}, R_{33}\right.$ and $\left.S_{55}\right)$ 23-week egg production averages of $75.3,78.5$, and 80.4 eggs, respectively. These values are slightly higher than those obtained in the present study, and may be a negative result from the selection for body weight. Kocak et al. (1995) recorded the 25-week egg production as $83.97 \%$, Canogullari et al. (2010), 12-week egg production between 87.74- 92.49\%, and Canogullari et al. (2016) reported 8-week egg production between 90.57 and $92.35 \%$ in Japanese quails. These values are higher than those obtained in the present study.

From 6 weeks of age, when the selection lines started laying, all eggs were weighed at 0.1-g precision once weekly. As shown in Figures 3 and 4, egg weight increased with age in both generations of both selection lines. In general, for the first generation, the $\mathrm{M}_{55}$ line laid heavier eggs in all weeks compared with the other lines, including when the egg weight average was calculated for the 18-week production period. For the second generation, egg weight difference was significant only in weeks 8, 15 and 18, and the. Egg weight in the 18-week average was not significant.

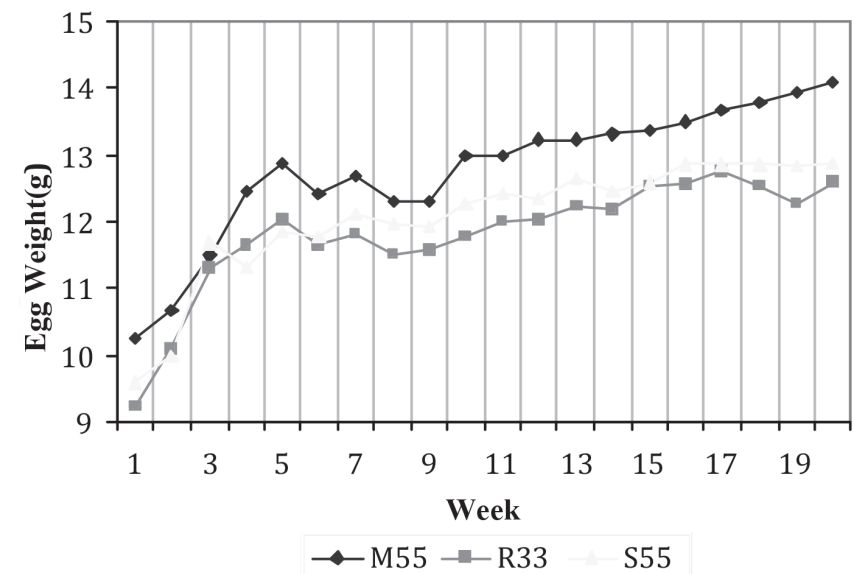

Figure $\mathbf{3}$-Weekly egg weight of the 1st generation of the selection lines

The egg weights of the $1^{\text {st }}$ generation determined for $M_{55}, R_{33}$ and $S_{55}$ lines in week 1 of lay were, in that order, $10.2,9.2$ and $9.6 \mathrm{~g}$, and in week 15 were, in the same order, $13.3,12.54$ and $12.5 \mathrm{~g}$, while the 20 - 
week average was calculated as 12.7, 11.9, and 12.1 $g$, respectively.

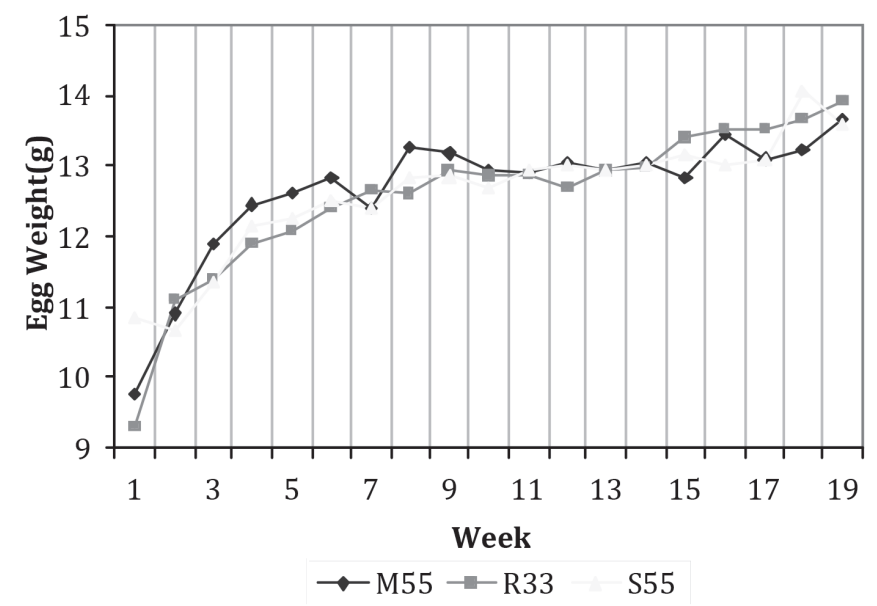

Figure 4 - Weekly egg weight of the 2nd generation of the selection lines

For the second generation, the egg weights of the $M_{55^{\prime}}, R_{33}$ and $S_{55}$ lines were determined as $9.7,9.3$, and $10.8 \mathrm{~g}$ in week 1 , as $12.8,13.4$, and $13.5 \mathrm{~g}$ in week 15; and the average egg weights calculated for the 18-week production period were 12.7, 12.5, and 12.5 $\mathrm{g}$. The egg weights of selection lines did not change much between generations. Baylan (2003) reported average egg weights over 23 weeks for $M_{55}, R_{33}$ and $S_{55}$ lines as $13.0,13.3$, and $12.8 \mathrm{~g}$, respectively. Working with Japanese quails, many researchers reported that egg weight increased as a result of selection for body weight (Woodard et al., 1973; Marks, 1976; Marks, 1979; Moritsu et al., 1997; Alkan et al., 2008). During their selection study of Japanese quails for high body weight in two different environments, Darden and Marks (1988) recorded increases of 1.4 and $1.3 \mathrm{~g}$ in egg weight after 11 generations. In the selection study for high body weight in week 4, under complete and split feeding conditions, Marks (1991) reported egg weights of 8.3 and $7.5 \mathrm{~g}$ in light lines and 11.7 and $10.8 \mathrm{~g}$ in heavy lines, respectively.

Testik et al. (1993) observed that in groups where selection for live weight was applied, egg weight increased, reporting egg weights of 13.0 and $12.8 \mathrm{~g}$ in selection groups of Aegean and Ankara origin. Inal et al. (1996) obtained egg weights between 12.01-13.23 $\mathrm{g}$ in their study on five generations selected for 5-wk body weight, and Alkan et al. (2013) obtained $12.22 \mathrm{~g}$ egg weight in a line selected for high body weight for 11 generations. Baylan (1998) reported average egg weights over 25 weeks of 13.0, 13.0 and $13.0 \mathrm{~g}$ in lines selected was applied for body weight at different ages $(3,4$, and 5 weeks of age) in the first generation; while for the $2^{\text {nd }}$ generation, 17 -week average egg weights of $11.9,12.4$ and 12.4 were obtained. Those authors suggested that the decrease in egg weight in the second generation might be related to environmental conditions. The results of the current experiment are consistent with those findings.

The egg weights obtained in the present study are higher than those reported by many researchers. Thomas and Ahuja (1988) reported 18-week egg weight at the end of two long-term selections for high body weight as 11.4 and $10.8 \mathrm{~g}$. Ariturk et al. (1980) reported the 90-day egg weights between 10.83 and $10.60 \mathrm{~g}$. Nacar et al. (1997), in their selection study for light and heavy 5-wk body weight observed heavier egg weights in the group selected for heavy BW, with 17-wk egg weight of $11.8 \mathrm{~g}$ in the heavy group and $11.6 \mathrm{~g}$ in the light group. In a similar study, Nacar (1998) obtained 16-wk egg weight of 11.9 in the heavy group, and $11.8 \mathrm{~g}$ in the light group. Alkan et al. (2008), in their study of selection in the heavy and light live weight, reported egg weights of $9.16 \mathrm{~g}$ in the light group and $11.26 \mathrm{~g}$ in the heavy group. All these reported Japanese quail egg weight values are lower than those calculated for all three selection lines in the present study.

\section{CONCLUSION}

This study applied different selection methods and evaluated egg production parameters in the parents and at the end of two generations of selection. While 5 -wk body weight values were higher in the second generation, no significant differences between generations in egg production levels was determined. However, in both generations, cross-selection lines presented higher egg production compared with the individual selection line. Continuing the selection of the aforementioned lines may be important, especially with regards to body weight. Selecting for carcass traits, in addition to body weight, in the development of paternal lines, while selecting for egg production and egg weight, together body weight, in the maternal lines is recommended.

\section{REFERENCES}

Alkan S, Karabag K, Galic A, Balcioglu MS, Yolcu I, Karslı T. Effects of body weight on egg production in Japanese quails (Coturnix coturnix japonica) in breeding summer season. Akdeniz University Journal of Agriculture Faculty 2008;21(1):35-40.

Alkan S, Karabag K, Galiç A, Karsli T, Balcioglu MS. Effects of selection for body weight and egg production on egg quality traits in Japanese quails (Coturnix coturnix japonica) of different lines and relationships between these traits. Journal of the Veterinary Faculty, Kafkas University 2010;16(2):239-244 
Alkan S, Karslı T, Karabag K, Galic A. The effects of selection and season on clutch traits and egg production in Japanese Quails (Coturnix coturnix Japonica) of different lines. Süleyman Demirel University Journal of Agriculture Faculty 2013;8(1):71-77

Anthony NB, Nestor Ke, Marks HL. Short-term selection for four-week body weight in japanese quail. Poultry Scence 1996;75:1192-1197.

Ariturk E, Aksoy T, Sengor E. Inheritance grades in quails (Coturnix coturnix japonica) and the effect of environmental conditions on the detection of various correlations. Ankara University Journal of Veterinary Faculty $1980 ; 22: 3-4$

Baylan M. Effects on productivity of divergent selection methods according to body weight in Japanese quail [thesis]. Hatay (Tur): University of Mustafa Kemal; 2003. Available from: http://fenbilimleri.mku.edu.tr/ tezadi.htm.2003

Baylan M. The efficiency of selection according to live weight at different ages in quails [thesis]. Adana (Tur): Sariçam/Adana: Cukurova University Agriculture Faculty Animal Science Department; 1998.

Baylan M, Canogullari S, Sahinler S, Uluocak, AN, Copur G. Effects of divergent selection methods based on body weights of quail on improvement of broiler quail parents. Journal of Animal and Veterinary Advances 2009a;8 (5):962-970.

Baylan M, Canogullari S, Sahin A, Copur G, Baylan M. Effects of different selection methods for body weight on some genetic parameters in Japanese Quail. Journal of Animal and Veterinary Advances 2009b;8(7):1385-1391.

Canogullari S, Baylan M, Erdogan Z, Duzguner V, Kucukgul A. Effect of dietary garlic on performance, egg yolk cholesterol and serum concentration in laying quails. Czech Journal of Animal Science 2010;55(7):286-29.

Canogulları S, Baylan M, Erdogan Z, Copur Akpınar G, Kucukgul A, Duzguner $V$. Performance, egg quality and serum parameters of japanese quails fed diet supplemented with spiırulina platensis. Fresenius Environmental Bulletin 2016;25(12a):5857-5862

Comstock RF, Robinson HF, Harvay FH. A breeding procedure designed to make maximum use of both general and specific combining ability. Agronomy Journal 1949;41:360-367.

Daikwo SI, Dim NI, Momoh OM. Genetic parameters of some Egg Production traits in Japanese quail in a tropical Environment. Journal of Agriculture and Veterinary Science 2014;7(9):9-42

Darden JR, Marks HL. Divergent selection for growth in Japanese quail under split and complete nutritional environments. 1. Genetic and correlated responses to selection. Poultry Science 1988;67:519-529.

Durmus I, Alkan S, Narinc D, Karabag K, Karslı T. Effects of mass selection on egg production on some reproductive traits in Japanese quail. European Poultry Science 2017;81. Available from: DOI:10.1399/ eps.2017.168

Hussain J, Akram M, Sahota AW, Javed K, Ahmad HA, Mehmood S, et al. Selection for higher three-week body weight in Japanese quail: 2 . Estimation of genetic parameters. The Journal of Animal \& Plant Sciences 2014;24(3):869-873.

Inal ŞS, Dere S, Kırıkcı K, Tepeli C. The effects of selection for body weight of Japanese quail on egg production, egg weight, fertility, hatchability and survivability. Veterinary Science Journal 1996;12(2):5-14.

Kayang BB, Vignal A, Inoue-Murayama M, Miwa M, Monvoisin J, Ito S, et al. A first-generation microsatellite linkage map of the Japanese quail. Animal Genetics 2004;35:195-200.

Kaye J, Akbap GN, Alphonsusc C, Kabird M, Zahraddeene D, Shehuf DM. Responsed to Genetic improvement and heritability of egg production and egg quality traits in japanese quail (Coturnix coturnix japonica). American Scientific Research Journal for Engineering, Technology and Sciences 2016;16(1):277-292.

Kocak C, Altan O, Akbas Y. An investigation of different production traits of Japanese quails (Coturnix coturnix Japanica). Turkish Journal of Veterinary and Animal Science 1995;19(1):65-71.
Maiorano G, Sobolewska A, Cianciullo D, Walasik K, Elminowska-Wenda $G$, Sławińska $A$, et al. Influence of in ovo prebiotic and synbiotics administration on meat quality of broiler chickens. Poultry Science 2012;91:2963-2969

Marks HL. Changes in unselected traits accompanying long-term selection for 4-week body weight in Japanese quail. Poultry Science 1979;58:269-274

Marks HL. Divergent selection for growth in Japanese quail under split and complete nutritional environments. 4. Genetic and correlated responses from generations 12 to 20. Poultry Science 1991;70:453-462.

Marks HL. Long-term selection for body weight in Japanese quail under different environments. Poultry Science 1996;75(10):1198-1203.

Marks HL. Long-term selection for four-week body weight in Japanese quail following modification of the selection environment. Poultry Science $1989 \cdot 68 \cdot 455-458$

Marks HL. Relationship of embryonic development to egg weight on fertility and hatchability in white leghorn birds. Poultry Adviser 1976;16(6):3738.

Minvielle F, Monvoisin Jl, Costa, J, Frenot A, Maeda Y. Changes in heterosis under within-line selection or reciprocal recurrent selection: an experiment on early egg production in Japanese quail. Journal of Animal Breeding and Genetics 1999;116:363-377

Minvielle F. Genetics and breeding of Japanese quail for production around the world. Proceedings of the 6th WPSA Asian Pacific Poultry Congress; 1998; Nagoya. Japan. p.122-127.

Moritsu Y, Nestor KE, Noble DO, Anthony NB, Bacon WL. Divergent selection for body weight and yolk precursor in coturnix coturnix japonica. 12 heterosis in reciprocal crosses between divergently selected lines. Poultry Science 1997;76:437-444

Nacar H, Uluocak AN, Baylan M, Ayasan T. The effects of selection according to five week body weight on egg production and egg weight. Trakya Region II. Proceedings of the Animal Husbandry Symposium; 1997 Jan 9-10; Tekirdag. Turkey. p.280-284.

Nacar $\mathrm{H}$, Uluocak AN. The effects of parentage age on the production of broiler quail. Proceedings of the YUTAV'95 International Poultry Fair and Conference; 1995 May 27; Istanbul. Turkey. p.81-87.

Nacar H. Identification of lines for the development of quail parents [phd thesis]. Sariçam/Adana: Çukurova University, Agriculture Faculty, Animal Production Department; 1998.

Narinc D, Aksoy T. Effects of multi-trait selection on phenotypic and genetic changes in a meat type dam line of japanese quail. Journal of the Faculty of Veterinary Medicine Kafkas University 2014;20(2):231-238.

Okan F, Uluocak AN. The effects of different crude protein levels in diet of quails on growth and carcass characteristics. TUBITAK-Nature Magazine, 1992;16:557-568.

Sarı M, Tilki M, Saatci M. Genetic parameters of slaughter and carcass traits in Japanese quail (Coturnix coturnix japonica). Bristh Poultry Science 2011;52:169-172.

Silva LP, Ribeiro JC, Crispim AC, Silva FG, Bonafé CM, Silva FF, et al. Genetic parameters of body weight and egg traits in meat-type quail. Livestock Science 2013;153(1-3):27-32.

Testik A, Uluocak AN, Sarıca M. Some yield characteristics of Japanese quails (Coturnix coturnix japonica) in different genotypes. Turkish Veterinary and Animal Husbandry Journal, 1993;17(2):167-173

Thomas PC, Ahuja SD. Improvement of broiler of CARI through selective breeding. Poultry Guide 1988;25:45-47.

Woodard AE, Abplanalp H, Wilson WO, Vohra P. Japanese quail husbandry in the laboratory. Davis: Deptarment of Avian Science University of California; 1973. p.1-24.

Yahaya HK. Oni OO. Akpa GN. Adeyinka IA. Evaluation of layer type chickens under reciprocal recurrent selection. Bayero Journal of Pure and Applied Sciences 2009;2(1):177-182 